\title{
Konflik Muslim Rohingya dalam Bingkai \\ Tiga Media Islam di Indonesia
}

\author{
Anggi Septa Sebastian
}

Alumnus Program Studi Ilmu Komunikasi

Universitas Islam Indonesia (UII), Yogyakarta

\section{Iwan Awaluddin Yusuf}

Dosen Program Studi Ilmu Komunikasi

Universitas Islam Indonesia (UII), Yogyakarta

\begin{abstract}
Rohingya Case in Myanmar attracted the attention for a number of Islamic media in Indonesia, including eramuslim.com site, Republika daily and Sabili magazine. Although all three of Islamic media covering the same case, and even with the same sources, but there are striking differences between all of them. eramuslim.com framing the case as a case of violence involving name of religion. Republika daily saw this case as a organized violation of the law until to be a problem that also resolved by the Non-Aligned Movement. While the Sabili magazine saw as injustice in making policies by Myanmar government that make an oppressed Rohingya by various sides.
\end{abstract}

Keywords: Rohingya Moslem, Islamic media, eramuslim.com site, Republika daily, Sabili magazine.

\begin{abstract}
Abstrak
Kasus Rohingnya di Myanmar telah menarik perhatian berbagai media Islam di Indonesia, termasuk situs eramuslim.com, harian Republika, dan majalah Sabili. Meskipun ketiga media tersebut sama-sama media Islam, namun terdapat perbedaan cukup menonjol dalam melakukan framing pemberitaan tentang kekerasan yang mengatasnamakan agama. Harian Republika melihat kasus ini sebagai kekerasan terorganisir terhadap hukum sampai menjadi masalah yang harus diselesaikan oleh Gerakan Non Blok (GNB). Sementara itu, Sabili memandang kasus ini sebagai ketidakadilan pemerintah Myanmar dalam memutuskan kebijakan. Akibatnya, kaum Rohingya merasa ditekan dari berbagai sisi.

Kata Kunci: Muslim Rohingnya, media Islam, eramuslim.com.site, harian Republika, majalah Sabili
\end{abstract}

\section{Pendahuluan}

Juni 2012, masyarakat dunia dikejutkan dengan kasus yang melibatkan unsur SARA. Kasus ini terjadi di Myanmar dan lebih dikenal dengan Kasus Muslim
Rohingya. Kasus ini bermula pada 28 Mei 2012. Seorang gadis Buddha, Ma Thida Htwe (28) dari Desa Kyauknimaw dilaporkan tewas ditikam di hutan dekat jalan menuju Kyaukhtayan, saat pulang 
bekerja sebagai tukang jahit. Kasus tersebut dilaporkan sebagai kasus pemerkosaan dan pembunuhan.

Kasus yang melibatkan kekerasan terhadap Muslim Rohingya di Mnyanmar sebenarnya sudah lama terjadi. Bukan hanya etnis Muslim Rohingya, hampir seluruh etnis minoritas di Myanmar mengalami penindasan yang serupa. Namun informasi mengenai hal itu sangat sulit didapatkan. Hal ini karena pemerintahan Junta Militer mengontrol secara ketat arus informasi yang masuk dan keluar. Hal seperti ini serupa dengan yang pernah Indonesia alami saat pemerintahan Orde Baru berkuasa.

Saat ini, Myanmar sedang dalam proses transisi menuju pemerintahan demokrasi. Pers dengan serta merta dapat turut melihat secara lebih mendalam mengenai apa yang terjadi di Myanmar. Termasuk konflik Muslim Rohingya. Hal ini menarik perhatian media di Indonesia, khususnya media Islam. Terlebih saat kasus Muslim Rohingya kembali mencuat karena bentrokan yang terus terjadi antara Muslim dan Buddha.

Beberapa pers Islam Indonesia yang turut meliput kasus Muslim Rohingya ini di antaranya adalah Situs eramuslim.com, Harian Republika dan Majalah Sabili. Ketiga media ini dipilih karena mewakili masing-masing karakter media massa. Situs eramuslim.com sebagai media online unggul pada sisi kecepatan berita. Harian Republika lebih

teratur dalam hal penebitan, selain itu juga berita yang dicetak terdokumentasikan. Sedangkan majalah Sabili unggul dalam hal kedalaman berita.

Dengan segmentasi yang berbedabeda, tentu saja ketiga media ini memiliki kebijakannya masing-masing. Baik yang terlihat maupun yang tak terlihat. Terlihat menyangkut bagaimana berita tersebut diturunkan, seperti apa kata-kata yang digunakan, dan seberapa besar porsi untuk satu berita. Sedangkan yang tidak terlihat adalah bagaimana redaksi mentukan tema yang diangkat dan sudut pandang yang digunakan dalam melihat berita. Dalam kaitan ini media melakukan seleksi isu dan penonjolan aspek (Eriyanto, 2012: 233-236).

Media dengan mekanisme yang sedemikian rupa memiliki kebijakannya masing-masing. Kebijakan inilah yang membuat media berjalan ke arah yang dituju. Demikian pula dengan media Islam. Dengan ideologi Islami, pers Islam dianggap partisan karena selalu memandang isu dari sudut pandang keIslaman. Akibatnya sudut pandang pers semakin mengerucut dan hanya bisa dinikmati oleh kalangan-kalangan tertentu saja.

Media dengan kebijakannya
masing-masing sudah seharusnya
memenuhi kewajiban fungsi persnya,
yakni sebagai media informasi,
pendidikan, dan kontrol sosial. Demikian


Anggi Septa Sebastian \& Iwan Awaluddin Yusuf, Konflik Muslim Rohingya dalam Bingkai Tiga Media Islam di Indonesia

pula dengan media Islam, termasuk dalam melihat kasus Muslim Rohingya ini.

Penelitian ini bertujuan untuk mengetahui bagaimana kasus pemberitaan Muslim Rohingya dibingkai oleh Situs eramuslim.com, harian Republika dan majalah Sabili. Untuk itu, fokus penelitian ini adalah pada beritaberita yang terkait dengan Muslim Rohingya yang diturunkan pada rentang waktu Juni-November 2012, di mana kasus tersebut sedang hangat dibicarakan.

Penulis menganggap bahwa masalah pemberitaan mengenai Muslim Rohingya oleh media Islam di Indonesia layak untuk diteliti. Hal ini dikarenakan Indonesia adalah negara dengan mayoritas Muslim yang besar namun sangat sedikit media yang mengusung nama Islam jika dibandingkan dengan media-media lain. Selain itu masalah Rohingya ini merupakan masalah yang berskala internasional. Terbukti dari bagaimana negara-negara lain turut peduli dalam upaya menangani kasus Muslim Rohingya. Pertimbangan lainnya, apa yang terjadi di Myanmar merupakan pelanggaran hak asasi manusia dan menerabas batas-batas SARA, yang mana adalah isu yang sangat sensitif di seluruh dunia saat ini.

\section{Islam dalam Berita}

Riset tentang Islam dalam berita pernah dilakukan oleh Janert Steele (2011). Ia meneliti mengenai bagaimana
Islam memandang praktik kerja jurnalistik. Penelitian ini dilakukan menyusul gencarnya pemberitaan tentang Islam dan Muslim pasca tragedi 9/11, disusul tragedi bom Bali dan Jakarta. Penelitian ini kemudian diterbitkan dalam jurnal berjudul "Justice and Journalism: Islam and Journalism Values ini Indonesia and Malaysia”. Hasil dari penelitian ini, Steele melihat bahwa jurnalis di Indonesia dan Malaysia mengekspresikan nilai jurnalisme yang umum tanpa menggunakan istilah-istilah yang terlalu Islami, lebih umum, serta melihat dan memahami arti dari apa yang mereka kerjakan dari sudut pandang Islam. Selain itu, pers di Asia Tenggara, khususnya Indonesia dan Malaysia, difungsikan sebagai media politik, sosial dan juga dakwah. Beberapa ciri pers Islam di Indonesia dan Malaysia antara lain Truth (Kebenaran), Verification (Verifikasi), Balance (Seimbang), Independences from power (Bebas dari kekuasaan).

M. Exsa Firmansyah (2008) juga pernah melakukan penelitian berjudl "Ideologi Islam dalam Harian Nasional". Riset akademik ini ditulis pada tahun 2008. Penelitian ini melihat kebijakan redaksional Harian Republika dalam masalah "Konflik Partai Kebangkitan Bangsa", "Ahmadiyah", dan "Kontroversi Film Fitna”. Hasilnya, Republika memposisikan diri sebagai media komunitas Islam yang tidak ingin melihat kaum Muslim terpecah belah dan merusak 
tatanan kerukunan yang telah ada. Selain itu Republika juga berusaha menjadi corong umat Muslim dan berusaha menjaga tali kerukunan antar umat beragama.

\section{Metode Penelitian}

Penelitian ini ini menggunaan analisis framing model Robert N. Entman. Menurut Entman, konsep framing digunakan untuk menggambarkan proses seleksi dan menonjolkan aspek tertentu dari realitas oleh media. Framing dapat dipandang sebagai penempatan informasi-informasi dalam konteks yang khas. Sehingga isu tertentu mendapatkan alokasi lebih besar daripada isu lain.

Framing dalam model Entman menggunakan empat langkah analisis. Berawal dari define problem, yaitu menganalisis tentang bagaimana masalah tersebut dilihat. Atau dilihat sebagai apa, dan sebagai masalah apa. Lalu analis berlanjut ke tahap kedua yaitu diagnose causes, langkah ini melihat: 1) Apa penyebab terjadinya sebuah peristiwa?; 2) apa yang dianggap sebagai penyebab dari suatu masalah?; 3) siapa (aktor) yang dianggap penyebab dari suatu masalah? Tahap ketiga analisis analisis berlanjut dengan menggunakan make moral jugdement, langkah ini melihat nilai moral apa yang berikan media untuk menjelaskan sebuah masalah, atau nilai moral apa yang digunakan media untuk melegitimasi atau mendelegitimasti suatu tidakan. Langkah yang terakhir dari model Entman ini adalah treatment recommendation, yaitu solusi atau penyelesaian apa yang ditawarkan untuk mengatasi masalah/isu.

Unit analisis dari penelitian ini adalah Harian Republika periode Juni, Agustus, September 2012, Majalah Sabili edisi Agustus dan Desember 2012, dan Situs eramuslim.com periode JuniNovember 2012. Ketiga media tersebut penulis pilih karena mempertimbangkan beberapa hal, di antaranya; Repulika sebagai harian nasional tentu saja memiliki jumalah pembaca yang banyak dan luas. Untuk itu peneliti beranggapan bahwa kebijakan yang diusung Republika bersifat universal terhadap semua golongan muslim. Kencenderungan Republika untuk condong ke salah satu golongan juga kecil.

Bertolak belakang dengan Republika, Majalah Sabili cenderung keras dalam menyerukan suaranya. Akibat dari sikapnya yang keras tersebut, majalah ini sering menjadi bahan pembicaraan di forum-forum internet dan di media sosial.

Lalu yang ketiga, penulis memilih media online eramuslim.com. pemilihan ini mempertimbangakan kekuatan media online disisi kecepatan dan kemudahan akses. Di saat dimana internet sangat mudah diakses, media onlinedipilih karena cepat, mudah, dan murah. eramuslim.com mewakili pers Islam di 
Anggi Septa Sebastian \& Iwan Awaluddin Yusuf, Konflik Muslim Rohingya dalam Bingkai Tiga Media Islam di Indonesia

dunia maya dan tidak terbit dalam versi cetak.

Selanjutnya, dalam memilih berita yang akan dianalisis, penulis menggunakan kata kunci "Muslim Rohingya", "Rohingya", dan "etnis Rohingya", untuk mempersempit unit berita yang akan dianalisis.

\section{Hasil dan Pembahasan}

\section{Temuan-temuan Utama}

a. Ketertindasan Muslim Rohingya

Dalam kategori "Kekerasan Antar Agama”, eramuslim.com melihat bahwa yang terjadi di Myanmar adalah pembantaian dan kekerasan yang dilatarbelakangi oleh nama agama, IslamBuddha. Islam diposisikan sebagai pihak yang tertindas. Pemicunya adalah penanganan aparat yang buruk atas tindakan kriminal yang terjadi beberapa waktu sebelum pecah bentrokan. Republika melihat apa yang terjadi di Myanmar sebagai pelanggaran hukum terorganisir serta tindakan anarkistis. Pemicunya adalah ketidakjelasan informasi. Sedangkan Sabili melihat apa yang terjadi di Myanmar sebagai ketertindasan Muslim oleh berbagai pihak. Pemicunya adalah perbedaan agama, etnis, dan bahkan tingkat ekonomi.

Namun demikian, penyelesaian masalah yang diberikan oleh ketiga media ini secara garis besar sama, yaitu penyelidikan yang terus dilakukan. Republika menambahkan himbauan kepada masyarakat agar menunjukkan rasa simpati sertamenahan diri dari tindakan melanggar hukum. Sedangkan Sabili menyarankan kepada masyarakat internasional untuk mengambil tindakan cepat serta mengamati proses reformasi di Myanmar.

b. Luka, Masalah dan Kecaman Dunia Islam

Situs eramuslim.com melihat peristiwa di Myanmar menimbulkan luka yang mendalam dan rasa simpati khususnya bagi umat Muslim. Hal tersebut dikarenakan rasa solidaritas umat Muslim yang tinggi, sehingga penderitaan yang dialami oleh Muslim Rohingya dapat dirasakan oleh umat Muslim di tempat lain. Berbeda dengan eramuslim.com, Harian Republika melihat apa yang terjadi di Myanmar adalah masalah tingkat tinggi yang perlu penanganan dari GNB (Gerakan Non Blok). Hal tersebut dikarenakan Republika menyamakan konflik Muslim Rohingya dengan apa yang terjadi di Suriah, Iran, dan Palestina. Majalah Sabili melihat bahwa dunia, khususnya dunia Islam tidak setuju dan mengecam dengan apa yang terjadi di Myammar.

Situs eramuslim.com menekankan pentingnya peran pemerintah Indonesia dalam upaya penyelesaian konflik di Myanmar. Sedangkan Republika menekankan pentingnya diplomasi antar 
negara-negara ASEAN. Berbeda dengan kedua media sebelumnya Sabili menekankan pentingnya rasa solidaritas antar sesama Muslim yang tinggi.

Penekanan penyelesaian yang diberikan ketiga media tersebut juga berbeda. Situs eramuslim.com menyarankan agar pemerintah Indonesia memberikan tekanan pada pemerintah Myanmar dan memberikan perlindungan bagi para korban yang mengungsi. Republika lebih memfokuskan penekanan penyelesaiannya kepada ASEAN agar memastikan komisi investigasi yang dibentuk oleh pemerintah Myanmar bekerja secara transparan. Sabili lebih menenkankan agar diambil tindakan tegas dan membawa persoalan ini ke jalur hukum, serta menekan pemerintah Myanmar melalui jalur diplomasi.

c. Keterlibatan Amerika

$$
\text { Dalam kategori ini, }
$$

eramuslim.com menonjolkan sisi ketidakpercayaan asing terhadap pemerintah Myanmar karena aparat yang ditugaskan untuk menjaga keamanan justru ikut menyerang Muslim Rohingya. Situs eramuslim.com tidak membenarkan tindakan represif dan diskriminatif kepada siapa saja. Untuk itu penyelesaian yang ditawarkan eramuslim.com dalam kategori "Keterlibatan Pihak Asing" ini adalah meningkatkan perlindungan dan simpati dari tiap Muslim serta perlunya dibuat undang-undang yang melindungi hak-hak minoritas.
Berbeda dengan eramuslim.com, Republika justru melihat adanya keterlibatan Amerika dalam penanganan konflik Rohingya. Hal ini sejalan dengan proses reformasi demokrasi yang terjadi di Myanmar. Republika melihat bahwademokrasi adalah tumpuan tumpuan dan harapan bagi semua. Penyelesaian yang ditawarkan Republika adalah membawa persoalan ini ke jalur hukum.

\section{d. Dari "Imigran Gelap” Menjadi} "Teroris"

Situs eramuslim.com melihat adanya kekejaman yang dilakukan kepada Muslim Rohingya, Republika menonjolkan sisi perlakuan diskriminatif yang dilakukan oleh pemeritah Myanmar. Sedangkan Sabili menampilkan sisi pergeseran status Muslim Rohingya dari yang sebelumnya imigran gelap menjadi teroris. Situs eramuslim.com dan majalah Sabili hampir sama dalam menentukan penyebab masalah, yakni adanya aksi kekerasan terhadap Muslim Rohingya. Hanya saja eramuslim.com menyebut aksi kekerasan itu dengan 'pembantaian', sedangkan Sabili dengan 'penyerangan'. Berbeda dengan eramuslim.com dan Sabili, Republika melihat penyebab masalah adalah karena warga Muslim tidak bisa berakulturasi dengan warga dari etnis lokal lainnya.

Untuk penyelesaian masalah pada kategori 'Korban' ini ketiganya memberikan penawaran yang serupa, 
yaitu memberikan bantuan kepada korban. Baik berupa bantuan logistik maupun pemberian status pengungsi.

e. Negosiasi, Penolakan, dan Balas Dendam

Situs eramuslim.com melihat bahwa konflik yang terjadi di Myanmar hanya didiamkan saja oleh pemerintah Myanmar, tanpa ada tindakan untuk mengatasi konflik. Sedangkan Republika lebih menyoroti peran Aung San Suu Kyi sebagai harapan perdamaian di Myanmar. Sabili melihat bahwa kebijakan yang diambil pemerintah tidak adil, karena pemerintah Myanmar memutuskan untuk mengusir Muslim Rohingya ke kampkamp penampungan yang dikelola $\mathrm{PBB}$.

Penyelesaian yang diberikan ketiganya pun juga berbeda. Situs eramuslim.com dengan tegas mengatakan bahwa akan ada aksi pembalasan terhadap kekerasan yang dilakukan kepada Muslim Rohingya. Republika menitikberatkan upaya penyelesaian melalui negosiasi dan membawa ke jalur hukum. Sedangkan Sabili menunjukkan penolakan terhadap kebijakan yang dibuat oleh presiden Myanmar

\section{Praktik Jurnalistik}

a. Situs eramuslim.com

Sebagaimana sifat media online yang unggul dalam hal kecepatan, eramuslim.com memberitakan peristiwa konflik di Myanmar bagai rentetan informasi yang update dalam hitungan menit. Dalam satu hari eramuslim.com bisa menurunkan dua sampai tiga berita terkait konflik di Myanmar.

Beberapa berita bahkan menunjukkan jika eramuslim.com hanya memperhatikan kecepatan saja. Ini terbukti dari berita yang belum selesai ditulis, namun segera diposting eramuslim.com terkesan terburu-buru dalam menurunkan berita.

Dalam penulisan berita eramuslim.com kurang memperhatikan unsur kelengkapan berita, seperti halnya $5 \mathrm{~W}+1 \mathrm{H}$. Beberapa berita hanya menekankan pada unsur What-nya saja. Beberapa lagi unsur-unsur yang lain menyusul menjadi semacam berita bersambung. Apa yang dilakukan eramuslim.com sudah tepat mengingat pembaca yang mengakses berita melalui portal online mengalami keterbatasan layar perangkat yang digunakan. Sehingga jika berita yang ditulis terlalu panjang, menimbulkan ketidaknyamanan bagi pembaca.

Situs eramuslim.com mengemas berita konflik Rohingya dengan sangat terbuka, ini terlihat dari penggunaan kata dalam judul dan body beritanya. Hampir pada setiap tulisan yang diturunkan terselip kata "bantai", "bunuh", "brutal", "tewas”, dan kata-kata yang mengarah pada unsur kekerasan.

Dalam hal tata tulis, eramuslim.com kurang memperhatikan 
kalimat jurnalistik yang baik. Seperti pada kutipan berikut;

Hal itu juga bisa memaksa Presiden Thein Sein, seorang mantan jenderal yang reformis, berhadapan dengan isu bahwa kelompok-kelompok HAM mengkritik selama bertahuntahun: eksodusnya ribuan muslim Rohingya yang tak punya negara yang tinggal di sepanjang perbatasan dengan Bangladesh dengan kondisi mengenaskan... (berita dengan judul 'Bentrokan Berdarah Antara Muslim dan Buddha Ancam Myanmar', 11 Juni 2012).

\section{Contoh lainnya misalkan:}

Menurut laporan media, warga di daerah terkepung itu tinggal di dalam rumah karena mereka takut kekerasan sektarian mematikan yang sedang berlangsung..." (berita dengan judul 'Kekerasan Berlanjut Terhadap Muslim Rohingya di Myanmar', 30 September 2012)

Kalimat di atas tidak menunjukkan penggunaan kalimat jurnalistik yang baik, cenderung bertele-tele dan tidak jelas gagasan utamanya. Padahal, yang menjadi patokan dalam penulisan kalimat jurnalistik hanyalah soal kejernihan isi berita agar pesan bisa sampai pada pembaca dengan baik (Dewabrata, 2004: 188). Selain itu kalimat tersebut juga menunjukkan bahwa berita yang dilansir dari sumber asing langsung diterjemahkan dalam bahasa Indonesia tanpa memperhatikan kaidah-kaidah pelansiran.

Terlepas dari itu semua, dalam mendefinisikan masalah, eramuslim.com melihat bahwa peristiwa yang terjadi di
Myanmar adalah pembantaian dan kekerasan komunal yang melibatkan nama agama, yakni Islam vs Buddha. Islam diposisikan sebagai pihak yang teraniaya oleh orang-orang etnis lokal yang mayoritas beragama Buddha, pemerintah, dan juga sistem kenegaraan. Situs ini juga menyebutkan adanya agenda pembersihan etnis oleh pemerintah Myanmar.

Situs eramuslim.com juga menyoroti tindakan pemerintah Myanmar yang, menurut eramuslim.com seolaholah mendiamkan konflik yang terjadi di Myanmar. Solusi yang ditawarkan eramuslim dalam menyelesaikan masalah pun terkesan beringas. Situs ini menyebutkan bahwa dunia perlunya melakukan embargo senjata dan ekonomi terhadap Myanmar terkait tindakan pemerintah Myanmar dalam upaya penyelesaian konflik. eramuslim.com juga memberikan ancaman akan adanya tindakan balas dendam dari kelompokkelompok Muslim di Asia.

Situs eramuslim.com juga tidak lupa menyoroti kebijakan yang diambil pemerintah Indonesia terkait dengan upaya penyelesaian konflik. eramuslim.com terus merongrong pemerintah Indonesia untuk melakukan desakan kepada Myanmar agar konflik ini segera berakhir.

Cara eramuslim.com mengemas berita terkait dengan konflik Rohingya menunjukkan karakteristik eramuslim 
Anggi Septa Sebastian \& Iwan Awaluddin Yusuf, Konflik Muslim Rohingya dalam Bingkai Tiga Media Islam di Indonesia

yang keras dan tegas. Bisa dikatakan, eramuslim adalah media Islam radikal.

b. Harian Republika

Berbeda dengan media sebelumnya, Republika, sebagai koran nasional memberitakan peristiwa di Myanmar dengan lebih tertutup. Walaupun media dengan nuansa Islam, namun Republika lebih memilih menurunkan berita-berita yang mengarah pada sisi perdamaian.

Terbukti dari nilai berita yang sering muncul adalah 'ketokohan', dan tokoh yang sering ditampilkan Republika terkait berita konflik Rohingya adalah Aung San Suu Kyi. Suu Kyi sendiri adalah tokoh reformasi Myanmar yang sempat menjadi tahanan rumah di era Junta Militer karena sering mengampanyekan demokrasi dan dianggap berbahaya. Kini, setelah pemerintahan Junta Militer runtuh dan berganti menjadi demokrasi, Suu Kyi dibebaskan dari status tahanan rumah. Beberapa waktu lalu dia bahkan menerima nobel perdamaian dan didaulat menjadi tokoh demokrasi Myanmar.

Republika menggambarkan konflik yang terjadi di Myanmar sebagai peristiwa pelanggaran hukum terorganisir yang dapat mengancam masa depan Myanmar. Bukan sebagai konflik antar dua agama, seperti yang eramuslim gambarkan. Pemicunya adalah ketidakjelasan informasi sehingga membuat orang-orang bertindak tanpa arah.
Solusi yang ditawarkan oleh Republika juga tidak terlalu keras seperti eramuslim.com. Republika menyarankan untuk membawa persoalan konflik ini ke ranah hukum, dan mengajak seluruh pembacanya untuk menunjukkan simpati terhadap konflik rohingya, serta menahan diri dari tindakan melanggar hukum. Selain itu Republika juga menyarankan untuk menyelesaikan konflik dengan cara yang disepakati kedua pihak yang berkonflik, yakni bernegosiasi.

Dalam hal waktu dan kebaruan, Republika masih kalah dengan eramuslim.com. Republika terhambat waktu cetak dan ruang. Tema-tema yang dipilih Republika cenderung mengarah pada upaya perdamaian melalui jalur diplomatik. Tidak ada kalimat-kalimat yang berkesan kekerasan pada tiap judul yang diturunkan, juga dalam isi beritanya.

Dalam penulisan, Republika lebih memperhatikan unsur kelayakan berita, yaitu akurat, lengkap, adil dan berimbang, objektif, ringkas, jelas, dan hangat (Kusumaningrat dan Kusumaningrat, 2006: 48). Walaupun tidak semuanya terpenuhi. Selain itu, Republika juga sangat memperhatikan unsur $5 \mathrm{~W}+1 \mathrm{H}$, sehingga beritanya lebih enak dibaca.

Dari nilai tokoh yang dimunculkan Republika, terlihat bahwa Republika adalah koran yang menjunjung tinggi semangat demokrasi. Dalam berita-berita yang terkait dengan konflik Rohingya pun, 
Republika menyebutkan bahwa demokrasi adalah tumpuan dan harapan bagi semua.

Dengan ini, Republika menempatkan dirinya sebagai surat kabar Islam yang tidak terjebak dalam perilaku partisan yang eksplisit. Islam yang ditampilkan adalah Islam yang kosmopolitan (Afifi, 2005: 314). Hal ini sesuai dengan slogan all you can read, mengingat Republika adalah koran nasional dengan segmen pembaca yang lebih variatif.

\section{c. Majalah Sabili}

Majalah Sabili juga memliki pandangan tersendiri mengenai konflik Rohingya. Sabili, sebagai representasi umat Islam (Afifi, 2005: 318) memandang konflik Rohingya sebagai tindakan yang tidak disetujui dunia dan menuai banyak kecaman.

Muslim diposisikan sebagai pihak yang tertindas oleh berbagai pihak, bahkan oleh media yang menyamakan Muslim Rohingya dengan Muslim garis keras. Sabili juga melihat menekankan isu bergesernya status warga Muslim Rohingya dari yang semula dianggap sebagai imigran gelap menjadi teroris. Tuduhan tersebut dilakukan pemerintah Myanmar dengan tanpa bukti. Menurut Sabili yang menjadi penyebab terjadi konflik adalah karena adanya perbedaan keyakinan, keragaman etnis dan juga kesenjangan ekonomi.

Namun dalam tawaran penyelesaian konflik, Sabili tidak berbeda jauh dengan Republika. Sabili menekankan untuk terus memberikan bantuan kepada pengungsi korban konflik. Sabili juga menyarankan agar persoalan dibawa ke jalur hukum.

Rentang waktu penerbitan yang lebih lama dari kedua media sebelumnya, eramuslim.com dan Republika membuat berita yang turunkan lebih mendalam dan lebih variatif karena biasanya ditulis dari berbagai sumber. Foto-foto tentang konflik Muslim Rohingya juga banyak ditampilkan mengingat ruang yang diberikan cukup banyak, yakni tiga sampai delapan halaman.

Kombinasi tata letak dan foto bisa dibilang paling baik dari dua media sebelumnya. Hanya saja isu Rohingya tidak menjadi isu utama dalam tiap edisi Sabili. Hal ini terlihat dari sampul yang dipilih Sabili, tidak satupun yang menggambarkan Muslim Rohingya sebagai isu utama. Bahkan menuliskan judul artikel tentang Muslim Rohingyapada sampul pun hanya satu kali di edisi 2 Agustus 2012.

Namun demikian, Sabili tidak terlalu terbuka dalam memberitakan konflik ini. Penggunaan judul tidak seprovokatif eramuslim.com namun juga tidak se-tertutup Republika. Tampak pada pemilihan kata judul tersebut Sabili ingin pembacanya meningkatkan rasa solidaritas sesama Muslim. 


\section{Perbandingan Antar Media}

Situs eramuslim.com cenderung keras dan seolah menebar permusuhan pada pihak-pihak yang menindas dan menganiaya Muslim. Hal tersebut dilakukan eramuslim.com melalui pemilihan kata yang digunakan pada judul dan body berita.

Sedangkan Harian Republika tidak sekeras eramuslim.com dan lebih menonjolkan sisi perdamaian dan juga upaya diplomasi untuk meredam konflik. Terlihat bagaimana Republika menggiring opini pembaca dengan sangat rapi dengan memunculkan isu dengan konsisten, tidak serampangan. Hal tersebut didukung dengan cara menuturkan yang baik dan lugas. Tampaknya jurnalis Republika sangat paham bagaimana menyajikan berita dengan cara memilih isu-isu yang jauh dari konflik, dan sebaliknya justru menghadirkan resolusi konflik dalam beritanya. Tentu saja ini tidak hanya berasal dari faktor wartawan saja.

Selanjutnya, Majalah Sabili lebih menekankan sisi solidaritas sesama Muslim. Dengan karakteristiknya, Sabili tidak menampilkan berita dengan terlalu terbuka atau terlalu tertutup. Kesan yang ditampilkan adalah tegas. Walaupun tidak menjadi isu utama, namun porsi yang diberikan untuk memberitakan Muslim Rohingya cukup banyak, yakni hingga delapan halaman. Perangkaian isu dari berbagai sumber tidak dilakukan secara serampangan. Agenda isu juga jelas, sama seperti Republika. Hal ini memungkinkan karena pada media cetak, proses seleksi isu lebih ketat dan berlapis (Syahputra, 2006: 55).

\section{Penutup}

Walaupun Situs eramuslim.com, Harian Republika dan Majalah Sabili memberitakan masalah yang sama, dengan sumber yang sebagian besar juga sama, ketiganya tetap menampilkan sisi yang berbeda.

Hal ini membuktikan bahwa selain menjalan fungsi sosial dan ekonomi, media juga menjalankan fungsi ideologis (Waziz, 2012: 3). Karena pada kenyataannya, pilihan makna dan simbol, sengaja atau tidak merupakan pilihan atas ideologi masing-masing media (Waziz, 2012: 73).

Keterbatasan penelitian ini terletak pada dokumentasi arsip berita yang penulis miliki tidak lengkap. Terutama untuk berita dari Harian Republika. Sehingga kurang menggambarkan konstruksi realitas media tersebut. Selain itu, penulis tidak melakukan penelusuran berita dari situs-situs yang dilansir. Dengan itu penulis tidak bisa menyimpulkan dengan yakin bahwa berita yang diturunkan oleh ketiga media tersebut benar-benar dilansir, sesuai dengan kaidah pelansiran atau hanya diterjemahkan. Penulis juga hanya menganalisis berita tekstual. Akan lebih lengkap rasanya jika penulis juga 
melakukan wawancara dengan pekerja ketiga media yang penulis teliti.

Penelitian selanjutnya, sebaiknya meneliti dengan menggunakan sudut pandang yang berbeda. Misalnya, politik keagamaan, relasi kuasa, ekonomi media, dan lain-lain.

\section{Daftar Pustaka}

Afifi, Subhan. 2005. "Profil Pers Islam di Era Reformasi”. Jurnal Ilmu Komunikasi, Volume 3 Nomor 3, (September-Desember 2005).

Dewabrata A. M. 2004. Kalimat Jurnalistik. Jakarta: Kompas.

Firmansyah, M.Exsa.2008. Ideologi Islam dalam Kebijakan Redaksional Harian Umum Republika. Skripsi Prodi Komunikasi FPSB UII

Eriyanto. 2012. Analisis Framing. Yogyakarta: LkiS.

Kusumaningrat, Hikmat dan Purnama Kusumaningrat. 2006. Jurnalistik: Teori dan Praktik.Bandung: Remaja Rosda Karya.
Syahputra, Iswandi. 2006. Jurnalisme Damai. Yogyakarta: Pilar.

Steele, Janet. 2011 Justice and Journalism: Islam and Journalistic Values in Indonesia and Malaysia. Wasington DC: SAGE

Tim Penyusun. 2008. Kamus Bahasa Indonesia. Jakarta: Pusat Bahasa Departemen Pendidikan Nasional.

Waziz, Kun. 2012. Media Massa dan Konstruksi Realitas. Malang dan Yogyakarta: Aditya Media. 